\title{
An Analysis of Current Mass Media Phenomenon from the Perspective of Theodor W. Adorno's Popular Music Criticism
}

\author{
Yikun Shen \\ Shanghai Publishing and Printing College, Shanghai, China \\ Email: 348440891@qq.com
}

How to cite this paper: Shen, Y. K. (2021). An Analysis of Current Mass Media Phenomenon from the Perspective of Theodor W. Adorno's Popular Music Criticism. Advances in Journalism and Communication, 9, 123-129.

https://doi.org/10.4236/ajc.2021.94010

Received: October 19, 2021

Accepted: November 19, 2021

Published: November 22, 2021

Copyright $\odot 2021$ by author(s) and Scientific Research Publishing Inc. This work is licensed under the Creative Commons Attribution International License (CC BY 4.0). http://creativecommons.org/licenses/by/4.0/

\begin{abstract}
This article analyzes Theodor W. Adorno's critical arguments on popular music from a sociological perspective, and explores the reference and enlightenment of his arguments on the problems of current mass media. Both mass media and popular music belong to the "cultural industry". It also has social characteristics of standardization, pseudo-individualization, entertainment and social cohesion. It lacks independent artistry and becomes an accomplice of capitalist ideology, causing the masses to lose their ability to think independently, and lose their spirit of resistance and criticism. This article aims to arouse people's in-depth reflection on the phenomenon of current mass media, and hope that mainstream media will make good use of the "double-edged sword" of mass media, and play a lead role to create a clean mass cultural environment, thereby promoting the positive development of mass media.
\end{abstract}

\section{Keywords}

Theodor W. Adorno, Popular Music, Criticism, Mass Media, Culture Industry

\section{Introduction}

Theodor W. Adorno (1903-1969) is a well-known German philosopher, sociologist, aesthetician and music theorist, and is a well-known important representative of the first generation of Frankfurt School, the founder of social critical theory. He has a strong interest in music and its theory, received professional training in music, published On Popular Music, New Philosophy of Music, Introduction to the Sociology of Music, Dialectic of Enlightenment and so on. Social character is the fundamental attribute of music, and music originates from 
society and reflects the reality of society in its own unique way (Deng Zhiwei, 2014). Adorno was good at sharply criticizing popular music from sociological and philosophical perspectives, which has a wide and far-reaching social influence. Mass media is on the exponential increase with the rapid development information. Its content, scope, speed, and influence are unprecedented, which seems to be a prosperous scene. But its essence, like popular music, is more of a "cultural industry" of standardized production. The word "industry" in the socalled "cultural industry", Adorno generally refers to a kind of "standardized" production, the result of which is that art, politics, religion, philosophy, etc. are all commercialized (Tang Wei, 2017). Therefore, drawing on Adorno's sociological critical theories of popular music and reflecting on the social characteristics and problems of modern mass media will help promote the positive development of mass media.

\section{Adorno's Critical Arguments on Popular Music}

Popular music is fundamentally different from serious music. Adorno divided music into popular music and serious music, believing that popular music, mainly jazz and blues, was part of cultural industrial production, and they have certain characters, which are standardization, pseudo-individualization, entertaining and the social cement (Adorno, 1941). Popular music is essentially commercial music, which is entertainment music created for the main purpose of making profits. It emphasizes marketability, and all aspects from the overall characteristics to the specific form and content are unified and standardized. If there are some differences in details, they are nothing more than standardized performance, pseudo-individualization, and lack of real artistry and creativity in essence, and yet the content is easy to understand, short in structure, lively and catchy. It is easy to be popularized and spread, and the public has a strong sense of participation and satisfaction. However, different from popular music, serious music, or art music, has outstanding artistic, academic, and ideological qualities. Each piece of serious music is an organic integrity with a rigorous structure that is every detail of the musical sense is derived from the whole of each piece of music. Each musical element is an independent individual, and has its own role in the whole. It is an organic combination of overall integrity and individual difference, and is inseparable. Serious music is highly innovative. Each different piece of music interprets profound propositions, is full of rich emotions, has superb creative skills, and is full of unique and eternal charm, which brings audience's different experiences, stimulate audience's imagination, constantly improve audience's aesthetic taste and appreciation ability, purify and sublimate the spirit world. However, to appreciate classical music properly, people also need professional training, including history, art and other aspects of knowledge combined to have a better understanding of classical music, which takes a lot of time, energy and money (Adorno, 1941).

Popular music leads to the loss of the possibility of autonomous art. Traditionally, the serious music, with independent style and value, is unique and cannot 
be copied. Unlike creation of serious music starting from blank, the formatbased music obeys regular patterns, obviously resulting in similar types of lyrics and tones. Although each song sounds different, the essence is the same and identical. The only change is the individual details (Adorno, 1941). The most successful music types can be imitated and have mass production. Driven by economic interests, popular musical creations are commodity production to cater to the taste of the mass instead of musicians' own free emotional expressions. The intrinsic experience of music gives the way to the external exchange value. Art thus goes down from the altar and becomes a commodity. In the past, music experience included live demonstration. People should be neatly dressed and give their whole attention to music when attending a concert (Scannell, 2007: pp. 5859). Nevertheless, people can now hear popular music everywhere and it no longer requires people to be absorbed, which can easily lead to mental confusion and the ability to appreciate it gradually deteriorates. With the reduction of varieties of music and fast consumption of music, people have less and less choices, the aesthetic appeal of the masses has gradually become superficial, individualized thoughts have also been gradually weakened, and the phenomenon of crowding and homogeneity is increasingly serious; hence, it harms the spiritual interests of the people. Through further comparison of popular music and serious music, it is clear that the consumption of popular music leads to the lost of possibilities of autonomous art (Scannell, 2007: p. 60).

The consumption of popular music makes music the accomplice of capitalist ideology and it cause the masses to lose possibilities of resistance or criticism. Popular music belongs to the entertainment industry system engaged with modern high technology, and ruling class takes it as a mean to integrate the ideology of the consumer and maintain their own interests. For example, every week, UK charts make a name list of hit singles for the public. To go with the tide, people will listen to these singles. Everyone has different taste and individuality, yet these ranking lists instill what is the most popular and best into people's mind. So in Adorno's view, popular music is not a progressive force that the mass media publicize. It is unable to truly express the will of the public, nor is it an experience towards a better future. It is just a tool that industrialists use to blind the public. This is the control of ideology. The ruling class keeps creating the mainstream ideas, and constantly giving advice to the public to make the majority of people agree with them (Adorno \& Horkheimer, 1997: p. 133).

In the on the Fetish-character in Music and the Regression of Listening, Adorno (1991) argues that the consumption of popular music contradicts the objective interest of those who consume it. The key reason for his insistence on this position in his argument is that popular music has lost the possibility of autonomous art and become an accomplice of capitalist ideology, thus depriving the masses of the possibility of resistance or criticism

All in all, Adorno (1991) believes that popular music has the characteristics of fetishism, which leads to the degradation of people's listening and appreciating ability. The consumption of popular music contradicts the objective interests of 
those who consume it. The key reason for his insistence on this position in his argument is that popular music has lost the possibility of autonomous art and become an accomplice of capitalist ideology, thus depriving the masses of the possibility of resistance or criticism.

The functional changes of music include the basic state of the relationship between art and society (Adorno, 1941), and music culture is closely related to social reality. From cultural criticism to social criticism is a distinctive feature of Adorno's critical theory (Luo Songtao, 2021). Adorno essentially reveals the social contradictions behind popular music through his criticism, and alerts the public to think about the path of ideological emancipation (Tu Rongzhen, 2021).

\section{Interpretation of Mass Media Phenomenon from Adorno's Perspective}

From Adorno's point of view, under the conditions of capitalist production, the "cultural industry" standardization of production methods has made mass culture homoousia and lost its autonomy and vitality. Mass media and "cultural industry" is a representation of the ideology of the ruling class, which is deceptive and has no real publicity. They have become tools to restrain self-consciousness and hinder individual development (Zhuang Xiyao \& Zhang Xueben, 2019).

Although today's mass media presents a complicated development trend of technology, diversification, and fashion, like popular music, mass media, as a product of commercial culture, will undoubtedly have vulgarization, standardization, and pseudo-personality in its production process. The characteristics and shortcomings such as transformation can easily lead to the loss of personal creativity, become a tool for the ruler to control people's ideology, and lead to the loss of public criticism. Therefore, Adorno's propositions are not limited to the music field, but also have the same warning effect on the interpretation of today's social phenomena of mass media.

Mass media can easily lead to the lost of ability to innovate. Literary and artistic creations have become a cultural industry, which are no longer spiritual products but products of unity and standardization. Take Chinese reality shows as an example. The Chinese television market has been glutted with reality shows recent years. It seems that Chinese reality shows are flourishing, while in fact, the vast majority of them purchase foreign copyrights to programme. For instance, the Voice of China is from British the Voice; and TV stations also introduce American the Amazing Race, Korean Running Man and so on to launch a Chinese version. Rarely do the Chinese reality shows blaze new trails, they mainly copy other countries' examples. In addition to that, no matter which type or style these shows are, names of programs, formats, game settings, invitations of guests and the contents are more or less the same. In different shows, show guests are all required to tug the airplane, hawk their wares in the streets, and imitate the ancients. Audience just get confused by which show it is. The choices people have are quite limited and they can only consume certain types of programs. 
Mass media easily becomes the tool for rulers to control people's thoughts and it makes the mass lose the ability of criticism. The masses are imbued with what is good and beneficial, and then they gradually lose their own judgments. When the mass media advocates that they are bringing happiness for the public, it is obviously deceiving consumers (Adorno \& Horkheimer, 1997: p. 139). After a day's hard working, people find popular media, which includes the popular music, the film, the newspaper and so on, a good method to release pressure and vent emotions. This kind of leisure activities do not require them to spend time thinking and the only thing they need to do is passively receiving the information that the mass media sends. The ideology is implanted in the art, and it has never been a real spiritual enjoyment for the masses. Certain values exist in all of them, and the government would use the mass media as a way to advocate its own ideology. They broadcast good news that is beneficial for the government and bad news of other countries on TV. In addition, when some celebrities win popularity in social media websites, such as Twitter, Facebook and Instagram, what they say spreads rapidly over the Internet. People are more likely to believe the words. As time goes by, the public becomes more and more petrified and they lose the spirit of resistance gradually. They are intended to receive information passively instead of thinking actively and losing the ability to think independently and their personality. Art ought to have helped people know the objective world, rethink profoundly and arouse the consciousness of resistance to their unequal statuses, yet it becomes an accomplice of ideology and plays a negative role in the society now.

\section{Analyze the Mass Media through the Limitations of Adorno's Argument}

Undoubtedly, Adorno's reflection still has an important enlightenment on the pros and cons of the development of popular music and mass media in today's society, but there are inevitably some shortcomings. For example, it does not provide empirical evidences for his theory and he uses too obscure and abstruse languages to express his idea. He adopts an elite attitude towards mass culture. And his criticism of music becomes a moral judgment that overrides form and social value (Zhang Jingjing, 2021). On the contrary, Walter Benjamin (1936) affirms the technology of mechanical reproduction, the mass media, and the production. He maintains that no matter what the time is, anyone cannot win over the masses with the elite art. It only works when the art is close to people's lives. John Fiske (1989) also considers that mass culture is not created by the culture industry, but by the masses themselves. Benjamin completely pays attention to the positive functions of the mass media while Adorno mainly sees the obverse side. In fact, since the mass media was born, it has been played a dual role. On the one hand, it breaks the monopoly of the elite art and culture and makes the masses get closer to art; on the other hand, it accelerates the process of the vulgarization and commercialization of art. The mass media enriches perception means for people and broadens their horizons while it limits people's abilities of 
imagination and creation. In addition, now in the era of big data, information can be shared, and the public can use the Internet platform to freely choose, communicate on an equal footing with producers of popular culture, and even directly become producers of popular culture, thus enabling popular culture to gain autonomy (Zhuang Xiyao \& Zhang Xueben, 2019). But it will also bring too much information, complex and complicated, mixed, confusing, and full of violence, pornography, star chasing, star speculation, money worship, excessive entertainment and other negative content that distorts human nature. Other than that, the mass media is a good way for people to vent their emotions, yet it also makes people lose rebellious spirit. The mass media could become a powerful weapon to against unfair distribution of social wealth; however, it could become the tool for rulers to control people as well. It all depends on how people treat it, use it and develop it.

Therefore, media workers should attach great importance to improving the spiritual connotation of popular culture, and creating a good atmosphere of popular culture, actively promote a large number of excellent works to guide the public to form correct consumer behaviors, and vigorously cultivate positive aesthetics and life values. For example, the popular TV series Merritories in China recently shows the true stories of the first eight "Republic Medal" winners, interpreting their ordinary and noble character, the lofty state of dedication to the motherland and all walks of life, and their hard work. The persevering spirit of struggle has been praised by the public, and it is bound to inspire more young people to follow their example and continue to fight for the strength of the motherland. We hope that similar excellent works will emerge one after another, prompting the mass media to continue to show positive energy. On October 29, 2021, the Propaganda Department of the Central Committee of China and the State Administration of Radio, Film and Television conducted interviews with the four provincial and municipal propaganda departments and radio and television stations on the over-entertainment of satellite TV programs, star chasing, and other issues, requiring resolute rectification and transformation. Requirement to focus more on the hot lives and strugglers and laborers of the new era, which shows that China is making further efforts to promote the positive development of mass media in the direction of enriching and leading the people's high-quality spiritual culture.

\section{Conclusion}

Overall, It is still of great significance to use Adorno's critical theory of popular music from a sociological perspective to study the issues of today's mass media. It is not difficult to find that mass media and popular music, as a product of industry culture, will undoubtedly have the characteristics and defects of vulgarization, standardization and pseudo-individualization in its production. It is easy to distract and blur the spirit of the masses and lose the spirit of criticism, enterprising and innovation. It is worthy of reflection. The mainstream media should establish a high sense of responsibility and mission, actively spread the positive 
energy, highlight the correction and leading ability, and promote the healthy development of mass media. Adorno's critical arguments will inevitably have some one-sidedness and limitations of the times, but through his critiques of popular music and other "cultural industry" systems, he reveals the contradictions behind society, and his critical spirit is still has far-reaching historical significance.

\section{Conflicts of Interest}

The author declares no conflicts of interest regarding the publication of this paper.

\section{References}

Adorno, T. W. (1941). On Popular Music. Zeitschrift für Sozialforschung, 9, 17-48. https://www.pdcnet.org/zfs/content/zfs $1941 \quad 00090001 \quad 0017 \quad 0048$ https://doi.org/10.5840/zfs1941913

Adorno, T. W. (1991). On the Fetish Characters in Music and the Regression of Lietening. In J. M. Bernstin (Ed.), The Culture Industry: Selected Essays On Mass Cuture (pp. 29-60). Routledge. https://doi.org/10.4324/9781003071297-2

Adorno, T. W., \& Horkheimer, M. (1997). The Culture Industry: Enlightenment as Mass Deception. In G. S. Nörr (Ed.), Dialectic of Enlightenment (pp. 120-167). Verso.

Benjamin, W. (1936). The Work of Art in the Age of Mechanical Reproduction. https://web.mit.edu/allanmc/www/benjamin.pdf

Deng, Z. W. (2014). Adorno's Ethical Criticism of Popular Music Consumption. Research in Ethics, 72, 91-97.

Fiske, J. (1989). Understanding Popular Culture. Unwin Hyman.

Luo, S. T. (2021). Dialectics of Free Time-Starting from Adorno's Critique of Culture Industry. Teaching and Research, 55, 105-112.

Scannell, P. (2007). Chapter 2: Mass Culture: Horkheimer, Adorno, Brecht, Benjamin, Germany/USA, 1930s and 1940s. In P. Scannell (Ed.), Media and Communication (pp. 3162). SAGE Publications.

Tang, W. (2017). Music under the Cultural Industry-Study on Adorno's Musical Aesthetic Thoughts. Art Criticism, 1, 19-21.

$\mathrm{Tu}$, R. Z. (2021). The Intermediary View in Adorno's Sociology of Art. Journal of Shandong University of Arts, 179, 124-128.

Zhang, J. J. (2021). On the Criticism of Adorno's Popular Music and New Media. Journal of the Central Conservatory of Music, 163, 130-140.

Zhuang, X. Y., \& Zhang, X. B. (2019). The Analysis of Mass Media in the Era of Big Data-Based on the Perspective of Adorno's Critical Identity. Journal of Shenyang Normal University (Social Science Edition), 2, 60-65. 